\title{
Initial Market Assessment for Small-Scale Biomass-Based CHP
}

White Paper NREL/TP-640-42046 January 2008

E. Brown and M. Mann 


\section{Initial Market Assessment for Small-Scale Biomass-Based CHP}

White Paper NREL/TP-640-42046 January 2008

E. Brown and M. Mann

Prepared under Task No. WF6N.1050

National Renewable Energy Laboratory 1617 Cole Boulevard, Golden, Colorado 80401-3393 303-275-3000 • www.nrel.gov

Operated for the U.S. Department of Energy

Office of Energy Efficiency and Renewable Energy

by Midwest Research Institute • Battelle

Contract No. DE-AC36-99-G010337

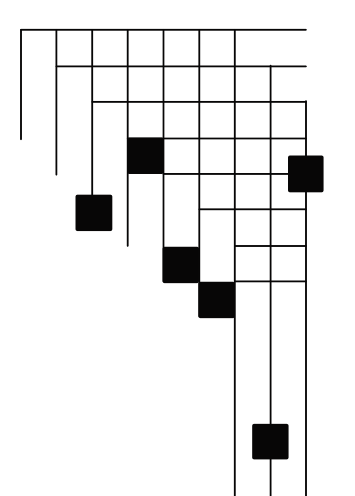




\section{NOTICE}

This report was prepared as an account of work sponsored by an agency of the United States government. Neither the United States government nor any agency thereof, nor any of their employees, makes any warranty, express or implied, or assumes any legal liability or responsibility for the accuracy, completeness, or usefulness of any information, apparatus, product, or process disclosed, or represents that its use would not infringe privately owned rights. Reference herein to any specific commercial product, process, or service by trade name, trademark, manufacturer, or otherwise does not necessarily constitute or imply its endorsement, recommendation, or favoring by the United States government or any agency thereof. The views and opinions of authors expressed herein do not necessarily state or reflect those of the United States government or any agency thereof.

Available electronically at http://www.osti.gov/bridge

Available for a processing fee to U.S. Department of Energy and its contractors, in paper, from:

U.S. Department of Energy

Office of Scientific and Technical Information

P.O. Box 62

Oak Ridge, TN 37831-0062

phone: 865.576 .8401

fax: 865.576 .5728

email: mailto:reports@adonis.osti.gov

Available for sale to the public, in paper, from:

U.S. Department of Commerce

National Technical Information Service

5285 Port Royal Road

Springfield, VA 22161

phone: 800.553.6847

fax: 703.605.6900

email: orders@ntis.fedworld.gov

online ordering: http://www.ntis.gov/ordering.htm 


\section{Acknowledgments}

This work is made possible by funding from the Environmental Protection Agency. The authors would like to thank Laura Vimmerstedt and Doug Arent of the NREL Strategic Energy Analysis and Applications Center, Anelia Milbrandt of the NREL GIS team, as well as Tom Frankiewicz and Kim Crossman of EPA for input and review of multiple versions of this report. The authors are also grateful to the insightful comments on previous drafts from Chris Lindsey of Antares, Chris Recchia of BERC, and Rick Handley of the NRBP. Stephanie Woodward, Jennifer Josey, and Michelle Kubik of NREL's Communications Office edited the report. Of course, any remaining errors are the responsibility of the authors. 


\section{Table of Contents}

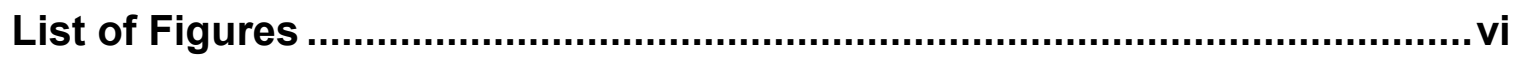

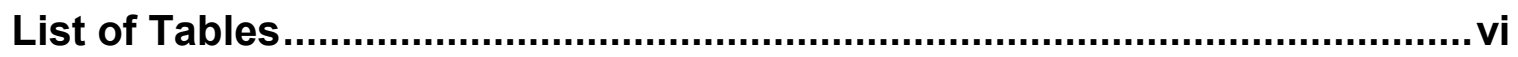

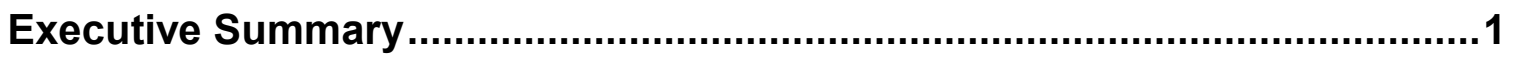

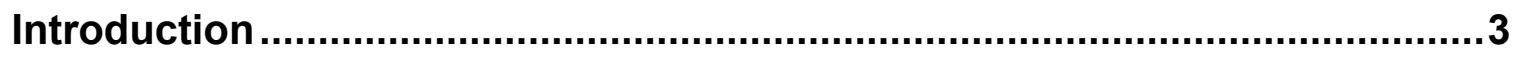

Section 1. Opportunities and Challenges for Small-Scale Biomass CHP......5

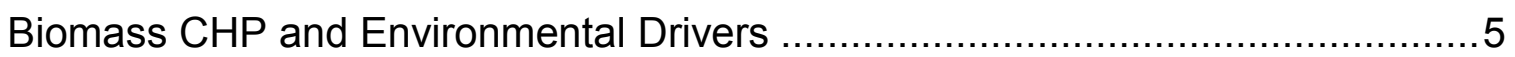

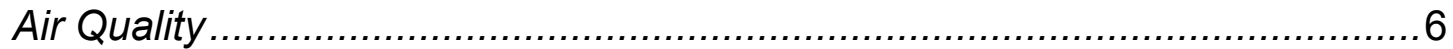

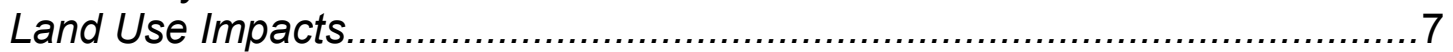

Forest Fire Reduction ......................................................................

Biomass CHP and Meeting Economic Drivers ............................................ 7

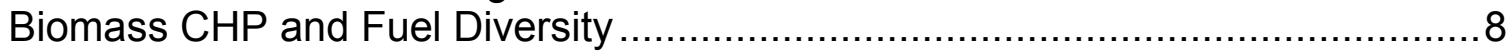

Section 2. Identifying Primary Markets for Small-Scale Biomass CHP..........9

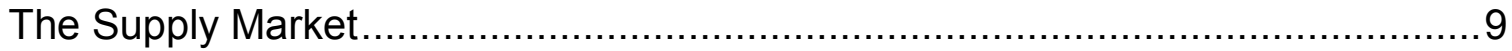

The Demand Market ............................................................................... 10

The Markets: Intersection of Supply and Demand .......................................10

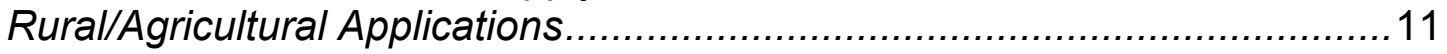

Municipal/Urban Applications .........................................................13

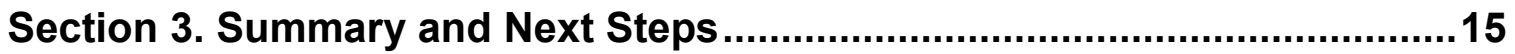

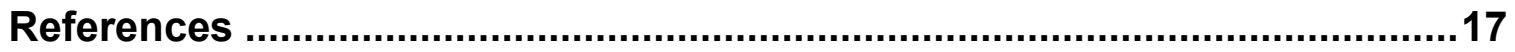




\section{List of Figures}

Figure ES-1. Crop and forest residues available in the United States and Counties with farm sales below $\$ 100,000$ per year

Figure 1-1. Crop and forest residues available in the United States and Counties with farm sales below $\$ 100,000$ per year

Figure 1-2. Map of U.S. Counties for reference to counties with less than $\$ 100,000$ annual average farm sales.

Figure 2. Urban biomass resources available in the United States

\section{List of Tables}

Table 1. Feedstock Sources Appropriate to Small-Scale Bioenergy 


\section{Executive Summary}

The current focus on liquid biofuel production has lessened attention on biomass for heat and electricity production, including biomass combined heat and power (CHP). The purpose of this white paper is to reexamine the energy generation market opportunities for biomass CHP applications smaller than $20 \mathrm{MW}$. Using relevant literature and expert opinion, this paper provides an overview of the benefits of and challenges for biomass CHP in terms of policy and economic drivers, and identifies the primary characteristics of potential markets. The paper does not quantify the market size, although possible analytic projects to identify market size are suggested for future analyses.

The literature reflects a growing consensus that the cost of biomass feedstocks will rise as biofuels demand increases. Centralized energy crops and those crops near biofuels production facilities may be used in biofuels development. Areas with diffuse biomass resources that are distant from biofuels production facilities and nearby small- to medium-sized electricity loads are likely markets for cost-competitive biomass CHP. More challenging to identify, but even more likely, are markets with appropriate thermal loads that make CHP a clear economic choice. In this report, the former and the latter markets are generally identified as:

- Small- to Medium-Sized Agricultural. This rural market can use crop, animal, and household residue, or collect nearby forest residue to minimize waste streams and stabilize electricity costs. Figure ES-1 illustrates areas with high numbers of small-scale (less than $\$ 100,000$ annual sales) agricultural businesses that coincide with high levels of forest and crop residues. These farms and businesses are the likeliest to be markets for smaller scale CHP because they are likely to have both the fuel and the necessary electric and thermal loads for demand. This preliminary assessment shows areas of high small-scale biomass CHP in the Northeast, Northwest, and central corridors.

- Municipal. This market can use urban wood, secondary mill, and landfill gas resources to provide electricity on a small scale for buildings within municipalities. This may reduce landfill expenses and space constraints, alleviate pressure on the grid, and provide more diversified electricity resources. This market benefits from the waste management system, an in-place infrastructure for collecting and distributing biomass that may be able to deliver fuel economically. The areas of highest potential for these markets surround densely populated urban areas, especially in southern California and the Northeast. 


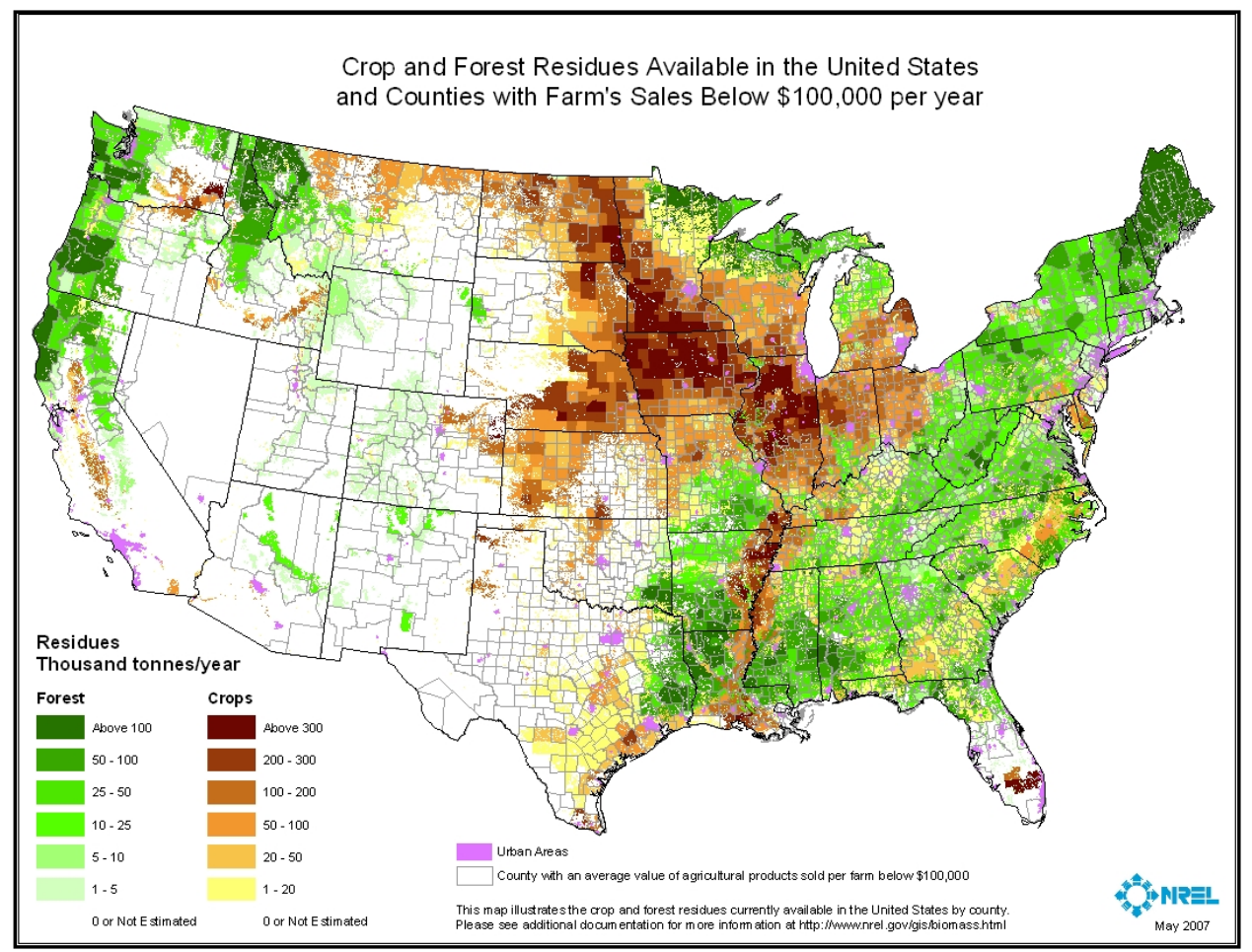

Figure ES-1. Crop and forest residues available in the United States and Counties* with farm sales below $\$ 100,000$ per year

*Note: Outlined counties are those with average annual farm sales below $\$ 100,000$. For a full map of counties, see body text.

The final section of the paper offers suggestions for further research and supportive policies to identify and encourage appropriate markets for biomass CHP. Specifically:

1) Provide more detailed geographic or regional analysis for targeted identification of markets

2) Conduct a review of regulatory and legislative policies in appropriate markets to identify policy opportunities

3) Identify incentive programs for appropriate markets based on positive experiences in other states

4) Develop a "best choice" fuel and technology guide for interested developers to help identify projects. 


\section{Introduction}

Biomass is plant matter such as trees, grasses, agricultural crops, and other biological material. It can be used as a solid fuel or converted into liquid or gaseous forms to produce electric power, heat, chemicals, and fuels. The biomass power industry grew rapidly from the late 1970s through the mid-1990s - from less than $200 \mathrm{MW}$ of biomass power capacity in 1979 to 6,000 MW in 1989 and to 6,500 MW today. This dramatic growth was spurred by the Public Utilities Regulatory Policy Act of 1978, which required utilities to enter into power purchase contracts with qualifying facilities for excess power at the utility's avoided cost. In recent years, low avoided cost has slowed the growth rate of the biomass power industry. As long-term contracts have expired or been repurchased by utilities, some biomass power facilities have closed.

Despite the diminished activity, waste streams need to be addressed and local electricity and disposal costs offset. Mill residues and other wood wastes (e.g., from municipal solid waste) are used to generate electricity to avoid landfilling and to generate power for onsite use. Agricultural residues are used to control wastes. This use has been encouraged, in part, to reduce the air quality impacts of open-field burning and the water impacts of applying wastes to fields. Landfill methane projects use methane that would otherwise be vented or flared, and displace conventional electricity generation. ${ }^{1}$

Using biomass to generate heat and power reduces net greenhouse gas emissions compared to fossil fuel-based generation. It can also offer air quality benefits compared to open burning of agricultural residues and coal-fired power plants. Because many biomass feedstocks - including residues from mill, forest, and agricultural operations, and manure from animal feeding operations - are concentrated in rural areas, biomass power facilities can benefit local, rural economies by creating jobs and tax revenues. Biomass power displaces fossil and alternative fuels used for generation and can contribute to a diversified energy mix.

Policy makers are focusing their efforts on the rapid development of the biofuels market rather than biomass-generated electricity or biomass CHP. This focus has raised feedstock competition and increased the price for feedstocks used in today's bioenergy facilities. Current and emerging research has been published about biofuels and their feedstocks (e.g., Paustian et al. 2006; Brown et al. 2007). The biofuels market is expected to expand significantly to meet national security and rural development goals in the next 10 years. Currently, biofuels market research activities focus on determining the costs and benefits of collecting and transporting feedstocks. Several important questions are being asked. Among these: How far can feedstocks be shipped for economic biofuels production? Which primary feedstocks will be used to develop biofuels? Where will these feedstocks be grown? Will they be dedicated energy crops or will alternative feedstocks be developed? The market will undoubtedly face these complicated feedstock and production issues in the coming decades.

\footnotetext{
${ }^{1}$ Larger scale bioenergy is also popular in certain applications, but is outside the scope of this effort. For example, the pulp and paper industry has been using on-site power systems to recover valuable chemicals from the black liquor and generate steam and electricity for the plant.
} 
This white-paper report identifies the characteristics of markets that would be appropriate for small-scale biomass CHP that will likely persist in the context of high-demand of biomass feedstocks for biofuels. The report does not quantify the size of the market, or attempt to make a case for the use of biomass feedstocks for CHP over biofuels, but instead identifies the characteristics of likely CHP markets. The dispersed biomass feedstocks are the focus for these markets because they may be too expensive to collect and transport for biofuels production. For this analysis, we assume that centrally-located feedstocks and energy crops will be dedicated to biofuels, and that cellulosic biofuels technologies will be commercially viable. These assumptions, while conservative, allow for a discussion of the opportunities for biomass CHP under highly competitive conditions. The discussion, then, centers on the remaining likely markets for small-scale biomass CHP. This report does not attempt to quantify the benefits of biomass CHP versus biofuels. Instead, we assume room for both markets because they use different primary choice feedstocks and because both can help to achieve national energy, environmental, and economic goals.

The report is divided into three sections:

- Section 1 includes a discussion of the drivers behind, and constraints on, the small-scale biomass CHP market.

- Section 2 provides a summary discussion of the available biomass supply types and technologies that could be used to feed this market. This section outlines the two primary markets - rural/agricultural and urban - for small-scale biomass $\mathrm{CHP}$, and illustrates the primary intersections of supply and demand for those markets.

- Section 3 summarizes the potential markets and suggests next steps for identifying and utilizing small-scale biomass. 


\section{Section 1. Opportunities and Challenges for Small-Scale Biomass CHP}

Historically, biomass feedstocks have been used for electricity through distributed and centralized generation. However, biomass CHP generation fell out of favor during the $20^{\text {th }}$ century when the coal transportation and delivery infrastructure matured to the point where coal could economically reach even the most remote areas. More recently, however, concerns about rural economic development, environmental protection, and national security have become important political drivers for biomass CHP development. Environmental drivers include local and global concerns. At the local level, air and water quality have a large impact on opportunities for biomass use. Globally, electricity generation is a major contributor to the emissions of climate-changing greenhouse gases. National security concerns include reducing our reliance on foreign petroleum imports. This driver is currently more relevant in the fuels sector than in the electricity sector, but the focus on self-reliance can still influence policy development for electricity generation, especially with respect to the importation of liquefied natural gas, and is particularly attractive to rural communities. Finally, economic development is an increasingly important driver for many energy policies, especially in terms of biomass energy in the fuels and electricity sectors. The primary interest is that biomass can increase supply markets and meet demand markets by keeping resources within a local economy.

These general drivers can create incentives for energy policy development, shape specific aspects of energy policy, or provide incentives and add urgency to its implementation. Considering different levels of government, national security is a driver for energy policy at the national level. At state and local levels, fuel diversity is seen as a way to protect consumers from price volatility.

The importance of any specific driver for energy policy varies by geographic region. Like most renewable resources, the drivers for biomass energy are closely related to the available resources. A clear example of this is the interest in corn-based ethanol in large corn-producing states like Iowa and Nebraska. Other states and localities, such as those with large forested areas or high-density urban areas, might focus on energy policy that includes forest fire reduction or local air quality impacts, respectively.

Although the impact of drivers varies by stakeholder or region, they all play a role in shaping approaches to biomass use. Thus, understanding the challenges of and opportunities for alternative electricity and thermal resources is critical to creating meaningful policies. The following subsections relate the capabilities and drawbacks of biomass electricity to each driver. They are presented in the order that is most likely to be important to prospective customers and local policymakers, because these markets will be highly localized.

\section{Biomass CHP and Environmental Drivers}

This section discusses the impacts that are most closely associated with biomass feedstock production and electricity as well as combined heat and power generation, including air quality and land use impacts and forest fire risk. The primary fuels for small-scale biomass CHP generation are residues that would otherwise need to be 
disposed of or alternatively used. Therefore, the impacts of biomass residues are compared to their alternate fates. Likewise, the impacts associated with growing energy crops for power generation should be considered in light of impacts associated with extracting and processing fuels such as coal, uranium, natural gas, and petroleum.

\section{Air Quality}

Electricity generation creates local and global air quality concerns. Local and regional air quality impacts include electricity generation emission of particulate matter and other pollutants that can cause human health problems. Note that the use of biomass for CHP can be largely more efficient and less polluting than biomass electricity generation without the thermal component.

Global impacts revolve around emissions of carbon dioxide as a greenhouse gas from fossil fuel combustion. Although biomass electricity involves carbon dioxide emissions, life cycle assessment studies confirm that sustainably-managed resources would reabsorb almost as much carbon because of the absorption of $\mathrm{CO}_{2}$ by the biomass during its growth, or the avoidance of decomposition emissions following biomass disposal. The net greenhouse gas emissions for biomass power are significantly less than those compared to fossil-based power systems (Bluestein 2000; Gagnon et al. 2002; Natural Scotland 2006; Spath and Mann 2001). Although some greenhouse gas emissions are released because of fossil fuel use during the planting, harvesting, and transporting stages of the life-cycle, total emissions are lower, regardless of the scale of production.

Information about local air quality impacts of small-scale biomass CHP generation is limited. The challenges associated with these types of studies are the assumptions that need to be made regarding the nature of the resource (e.g., municipal residue or wood residue) and assumptions regarding the efficiency of the technology and installed pollution control equipment. Some resource- or technology-specific research projects have been conducted (Natural Scotland 2006, for example), but a broad overview has not been published. In addition to the challenges associated with having many resources and technologies, the relative importance of local air quality varies depending on the area being served, and the relative impact of electricity generation technologies depends on the current local generation mix.

A number of studies offer general information on the local air quality impacts of smallscale biomass electricity. Both the EPA Web site (EPA 2007) and an independent 2002 paper summarizing life-cycle analyses of large-scale electricity generation plants find that biomass plants often produce lower sulfur emissions but higher nitrogen oxides than other generation types (Gagnon et al. 2002). This indicates that nitrogen oxide emissions consideration is especially important for siting small-scale biomass CHP plants, especially in urban areas that are already_or approaching — non-attainment for pollutants such as ground-level ozone or particulate matter.

Since small-scale biomass CHP will be located closer to the load center than central plants, effective total emissions will be reduced because of the elimination or reduction of transmission line losses. However, local air emissions impacts may be exacerbated if 
units that are responsible for greater emissions than central plants are located within more pollution-sensitive populated areas. Further research on these and other issues such as fuel cycle efficiency need to be addressed in future work quantifying the environmental impact of small-scale biomass-based CHP.

\section{Land Use Impacts}

Using wood or other biomass wastes to generate power can reduce the landfill space required for waste disposal. Waste wood generation and availability data for 1996 can be used to illustrate the potential benefits of using any of the biomass residues that are currently landfilled. Of the 193.5 million tons of waste wood generated that year, only 37.4 million tons, or $19.3 \%$, were available for use. The difference between what is generated and what is available is attributed to waste wood that is combusted, not usable (in some cases because of chemical contamination), or is already recovered for use (McKeever 1998). If this wood waste were diverted from landfills, about 250 fewer average-sized landfills would be needed in the Unite States (assuming a 144,540 ton-peryear intake rate per landfill). To put this number in perspective, in 1996 there were 2,417 landfills in the U.S. (Thompson 1998). Thus, diverting 37.4 million tons of wood waste would reduce the required U.S. landfill capacity by about $10 \%$. Additionally, utilizing these biomass resources could help reduce local waste disposal costs in urban areas.

\section{Forest Fire Reduction}

Using forest residues, including thinnings, for energy production rather than leaving them to accumulate in the forest can help mitigate forest fires, which result in property damage, air pollution, habitat loss, and in some cases, flooding and erosion (Morris 1999). Over the last 50 years, there has been a steady increase in the number of wildfires in the western U.S., particularly during the late 1980s and again in 2000, 2002, 2005 and 2006. At the same time, vulnerable real estate development areas have increased, putting more people and property at risk. According to the U.S. Forest Service, this increase in forest fire activity is a result of two factors:

1. Severe drought accompanied by millions of lightning strikes and windy conditions, and

2. Long-term effects of a century-long effort to suppress wildfires, which has led to an unnatural increase in the amount of brush and small trees in the forest understory (USDA Forest Service 2000).

Forest residues can provide a sufficient fuel supply for heat and power generation that can be harvested economically (NREL 2005).

\section{Biomass CHP and Meeting Economic Drivers}

The economic benefits of small-scale biomass CHP include increased local industry investment and reduced electricity price volatility for the on-site producer, and in some cases, the larger community. Those who produce power from local resources for on-site use benefit significantly from reduced price volatility. The benefits of long-term contracts for power purchasing of biomass CHP, however, are increasingly uncertain in an environment of increasing feedstock competition and may prove to be a significant 
challenge for small-scale distributed generation facilities hoping to sell excess energy. By internalizing energy production, renewable energy may reduce overall community and state energy import costs. In addition to these benefits, small-scale biomass CHP can:

- Recover waste for use in energy production and minimize and streamline waste disposal. This reduces waste management costs, including transportation and landfilling, which are often some municipalities' greatest expenses.

- Provide a use for underused fuels. Even as competition for mainstream energy crops intensifies with increasing biofuels production, crops and residues that are currently of low or no value, or too geographically distributed to be economically collected for biofuels use, are available to support the market for small-scale biomass CHP. Consumers that have the technology and the willingness to pay for these materials as they become more in demand will be able to make use of them.

- Use cost-effective technologies for a variety of cost-effective resources and applications. Detailed descriptions of the technologies are beyond the scope of this study, but there is a wealth of recent information for policy makers and project developers about available technologies (EPA Biomass CHP Catalog of Technologies). Note that biomass CHP may not be cost effective in highly competitive areas or those with relatively low electricity and heating fuel cost.

Another economic driver for combined heat and power is the avoided costs of alternative fuels. That is, relative electricity and heating fuel prices can increase the economic drivers for CHP development.

\section{Biomass CHP and Fuel Diversity}

The use of biomass for power generation offers multiple fuel diversification benefits. In 2000 , biomass was used to produce 64.1 billion $\mathrm{kWh}$ of electricity, or $1.7 \%$ of the total electricity generated in the U.S. (Haq 2002). Having multiple fuels available for electricity strengthens the resiliency of the grid in the event of increased air quality concerns (biomass could support coal use reductions) or resource supply disruptions. 


\section{Section 2. Market Characteristics for Small-Scale Biomass CHP}

Identifying the potential markets for small-scale biomass CHP is critical to developing the resource and achieving the benefits described in Section 1. This section identifies markets that may be appropriate for small-scale biomass power, and provides an overview of where markets are located in the U.S. This estimate of resource availability and demand can serve as a guide for project investors and policymakers looking to maximize homegrown, economically viable, lesser polluting fuels for electricity use and provide a basis for further research.

Two primary assumptions are associated with identifying the markets for small-scale biomass CHP:

1. Biofuels demand, assuming cellulosic ethanol, will absorb much of the energy crop and economically transportable high quality biomass stocks. In addition, we assume that biofuels production, because of the economics, will be large and central scale, as has been the case historically (RFA 2007).

2. Areas of electricity and heat demand are assumed to be very near to the distributed biomass resources remaining for use in small-scale biomass CHP.

\section{The Supply Market}

Biomass includes a broad category of feedstocks (EPA Catalog, Milbrandt 2005). We assume that competition for biomass feedstocks will increase as a result of increasing biofuels use. We further assume that energy crops are of high value in the competitive market and primarily used for biofuels production. Three primary sources for biomass can be used for biomass CHP (Milbrandt 2005):

1. Agricultural

a. Crop Residues - Unused portions of corn, wheat, soybeans, cotton, sorghum, barley, oats, rice, rye, canola, dry edible beans, dry edible peas, peanuts, potatoes, safflower, sunflower, sugarcane, and flaxseed.

b. Manure Biogas - Manure management systems for dairy and beef 2. Municipal cows, hogs and pigs, sheep, chickens and layers, broilers, and turkeys.

a. Landfill Gas - Total methane emitted from landfills.

b. Wastewater Treatment Biogas - Total emitted from wastewater treatment plants.

c. Food Processing Residue - Organic food wastes from municipal solid waste.

3. Wood

a. Urban Wood - Wood residues from municipal solid waste, utility tree trimmings, and construction and demolition sites.

b. Secondary Mill Residue - Wood scraps and sawdust from woodworking shops.

c. Forest Residue - Logging and other removable materials. 
Table 1 summarizes bioenergy residue sources, their availability nationwide, and magnitude of supply. This table does not represent an estimate of actual bioenergy or supply availability, which was beyond the scope of this report. The relative magnitude of the resource offers context to the demand discussion.

Table 1. Feedstock Sources Appropriate to Small-Scale Bioenergy

\begin{tabular}{|l|l|l|l|}
\hline $\begin{array}{l}\text { Residue } \\
\text { Source }\end{array}$ & Types & $\begin{array}{l}\text { Primary } \\
\text { Location }\end{array}$ & $\begin{array}{l}\text { Magnitude of Supply } \\
\text { (000 bone dry tons) }\end{array}$ \\
\hline Agricultural & $\begin{array}{l}\text { Crop residues } \\
\text { Manure biogas }\end{array}$ & \multirow{2}{*}{ Rural } & 157,194 \\
\cline { 4 - 4 } Municipal & $\begin{array}{l}\text { Landfill gas } \\
\text { Wastewater treatment biogas }\end{array}$ & \multirow{3}{*}{ Urban } & 2,189 \\
\hline \multirow{3}{*}{ Wood } & Food processing residue & 465 \\
& $\begin{array}{l}\text { Urban wood, including cuttings and } \\
\text { prunings }\end{array}$ & \multirow{2}{*}{ Urban } & Unknown \\
\cline { 2 - 2 } & Secondary mill residue* & 30,902 \\
\cline { 2 - 2 } & Forest residues & Rural & 56,615 \\
\hline
\end{tabular}

Source: Milbrandt 2005, EPA 2007

*Primary mill residues and other resources not listed here are assumed to be used in biofuels applications. See text for assumptions.

Power and heat production potential from small-scale biomass is technology and resource dependent. Each biomass type has different properties that will need to be addressed in developing system economics, technology choice, and use, but mature or demonstrated technologies are available. Detailed technology assessments are available (EPRI 1997; EPA 2007).

\section{The Demand Market}

Previous research illustrates that small-scale biomass CHP can be economically feasible when fuel does not need to be transported long distances (EPA Biomass CHP Catalog of Technologies). Therefore, demand must:

- Be located close to the supply, and

- Be correctly sized and applied to fit the supply amount, timing, and feedstock type available.

\section{The Markets: Intersection of Supply and Demand}

Under the supply and demand parameters, there are two primary applications for biomass CHP: agricultural/rural and municipal/urban. These applications are flexible enough to withstand significant changes in the biofuels market such as high demand and increased feedstock competition. These two supply markets create disparate resources, leading to high transportation costs that make them less valuable than centralized energy crops. Moreover, both markets have electricity demands that could benefit from reduced electricity price volatility and the opportunities for economic development and fuel diversity that result from local energy production and use. Given uncertain market fluctuations, however, the reader should keep in mind that the availability and cost of these resources may change. The remainder of this section details these markets. Figure 1-1 illustrates the markets geographically on a national scale. 


\section{Rural/Agricultural Applications}

Biomass-fired small-scale distributed generation in this market can offset electricity costs with local and available resources. In small- to medium-sized agricultural markets (less than $\$ 100,000$ in farm product sales annually), electricity costs can reach $10 \%$ of variable farm costs. Minimizing energy costs for this market segment can make the difference between economic success and failure (Brown and Elliott 2005). The primary supply in this market is accessible rural wastes such as crop residues, methane biogas, and forest trimmings. Of these, crop residues and methane biogas are more easily collected and centralized, improving the economics of electricity production. Forest thinnings are more dispersed but may still be economical to collect, especially in light of the forest fire prevention benefits.

Figure 1-1 presents a rough visual overlap of rural supply and demand to represent this potential market. Counties (outlined in gray) with agricultural sales less than $\$ 100,000$ per year represent the demand market (Data supplied by NREL GIS 2007). Figure 1-2 stands as a reference for comparison of all counties to those with less than $\$ 100,000$ in farm sales. Supply is measured in dry tons of available biomass by type (feedstock specific supply maps and state are available in Milbrandt 2005). The coincidence of outlined counties and darker supply areas indicates the most likely markets for biomass CHP. In these areas, the electricity and likely thermal load demand of small farms correlates with the supply of residues from small farms, ranches, and forests. Counties with average annual sales per farm of $\$ 100,000$ per year or less are used to approximate those areas where resource collection for conversion to biofuels might face greater challenges. While numerous small farms in a high yield region could produce resources for biofuels, we assume that as a first approximation biomass resource from counties with larger farms will prove more attractive due to logistical and contractual considerations. 


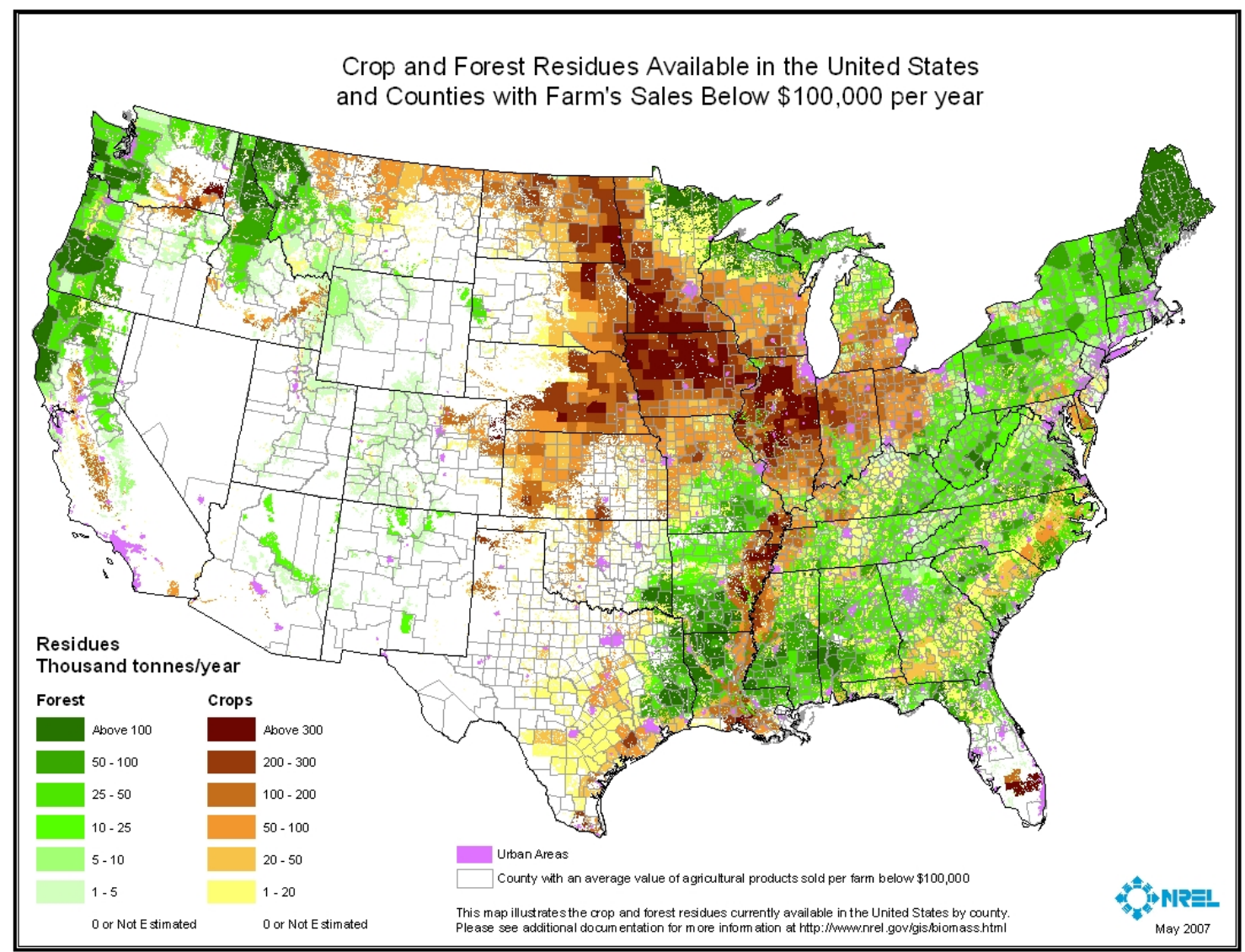

Figure 1-1. Crop and forest residues available in the United States and counties with farm sales below $\$ 100,000$ per year*

*Note: Crop and forest residue coincidence with small average agricultural sales per business counties. Outlined counties are those with average annual farm sales below $\$ 100,000$. For a full map of counties, see Figure 1-2. 


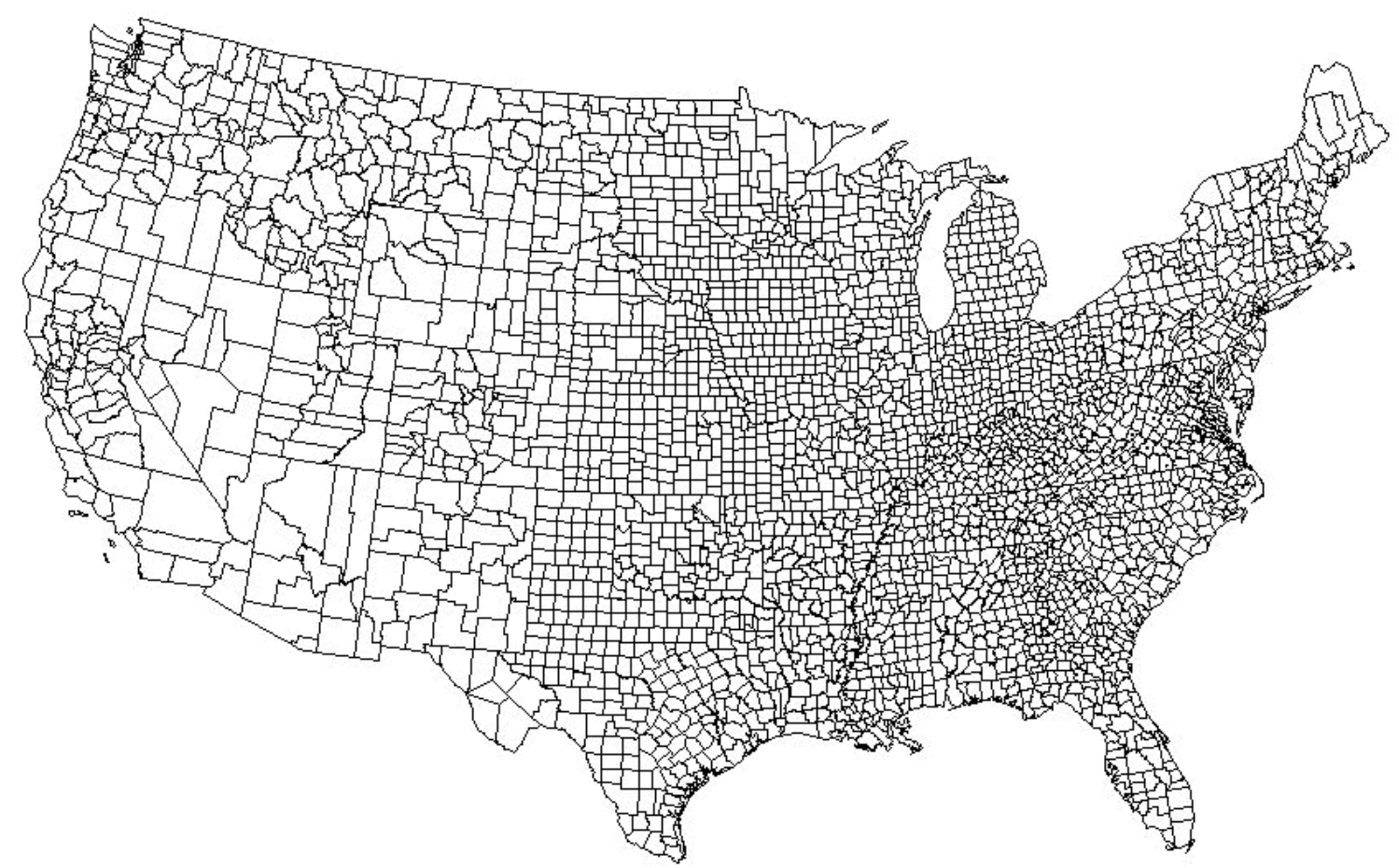

Figure 1-2. Map of U.S. counties for reference to counties with less than $\$ 100,000$ annual average farm sales

\section{Municipal/Urban Applications}

The second potential market is municipal/urban applications. The supply for these applications comes from secondary mill residues, urban wood wastes, methane gas from landfills, and domestic water treatment. Multiple resources (Milbrandt 2005; EPA 2007) offer complete descriptions of the resource types as well as benefits and challenges of their use. Urban demand applications for combined heat and power include applications in buildings (e.g., industrial and large commercial) and backup electricity generation in congested areas.

Figure 2 illustrates the regions of the country with the largest supply of this type of resource. The darker areas indicate large supplies of urban residues for fuel and a high demand for the electricity. Because of the nature of supply resources and demand locations, there is a great deal of overlap, and therefore, a great deal of opportunity for small-scale CHP in the large urban markets. 


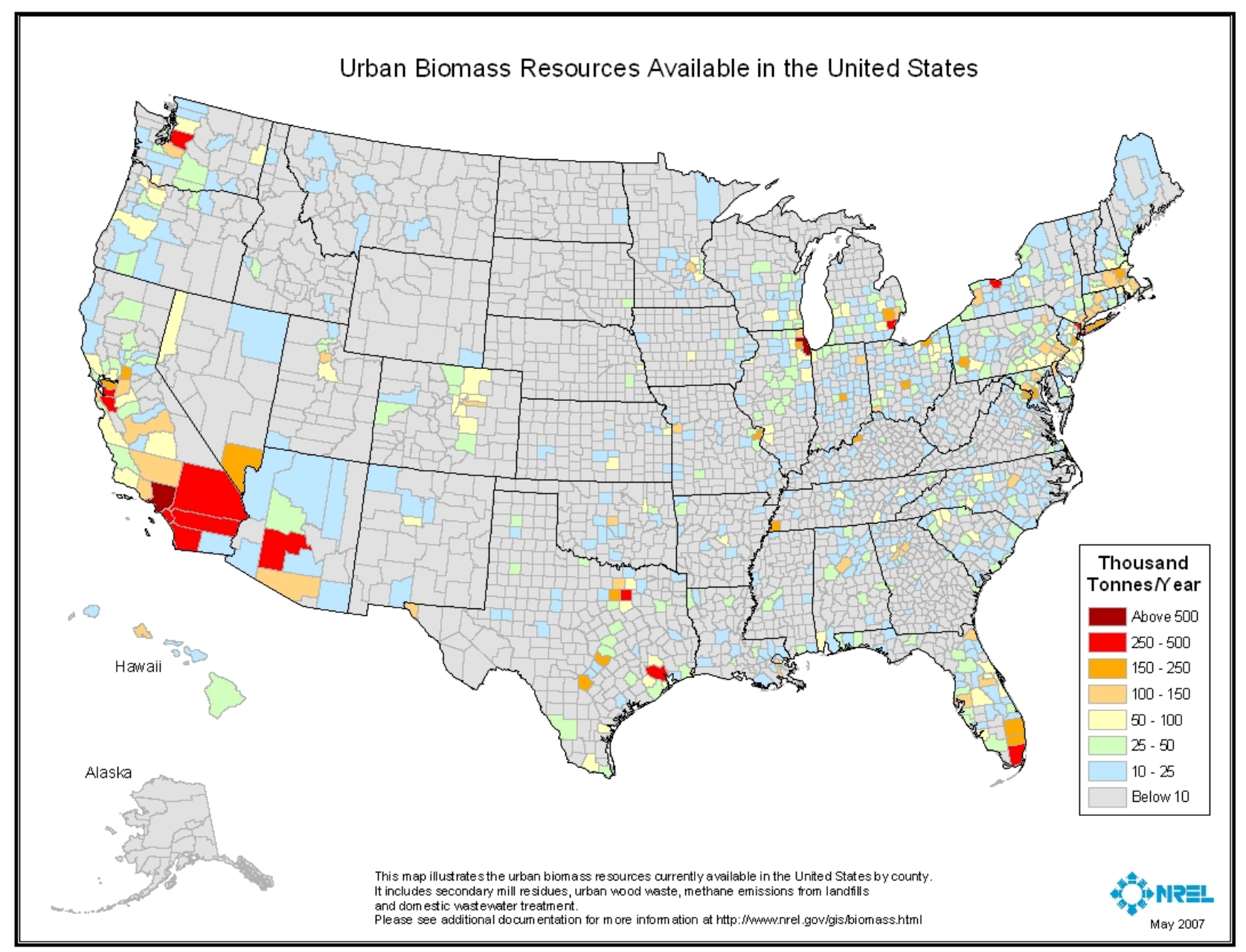

Figure 2. Urban biomass resources* available in the United States

*Note: Resources include landfill gas, wastewater treatment biogas, food processing residue, urban wood, and secondary mill residue. 


\section{Section 3. Summary and Next Steps}

This report establishes that there are existing, viable markets for small-scale biomass utilization in terms of feedstock supply and demand for onsite, distributed thermal and electrical energy production. Stronger interest in biofuels production from lignocellulosics (woody and herbaceous biomass) will presumably reduce the availability of centralized biomass feedstocks for electricity use, but distributed feedstocks will remain available for use close to their source. The likely markets include urban demand areas coinciding with urban residue, landfill gas, and agricultural demand markets close to agricultural and forest residues.

To capture these markets, further research and deployment activities, from basic understanding to program implementation and monitoring, are necessary. The following suggestions are presented as next steps needed for additional research and documentation of potential markets and best practices, to encourage biomass CHP:

1. Develop a more detailed geographic and quantitative analysis to better understand the distribution and specific locations of favorable markets for small-scale biomass CHP development. A regional analysis of favorable markets that use more specific demand data and electricity prices would provide greater insight into the likelihood of economic adoption of existing technologies. Because of the dispersed nature of the markets, very fine resolution data or individual site characteristics may be needed to identify and develop specific sites. For large areas that have a high likelihood for a market (such as the Los Angeles Basin), tools and education programs can help private industry identify and develop sites. Long term, a Web-based application developed for public and private industry could identify areas of available resources and demand for these facilities by incorporating impact analysis tools to providing market information.

\section{Thoroughly review regulatory and legislative policies in appropriate}

markets. Understanding the barriers to market development in select regions allows for programs to be tailored specifically to regional needs, and would contribute to program design for increased market penetration. In addition, identifying areas with policies that encourage economic development could help prepare the market for increased biomass CHP.

\section{Identify and evaluate incentive programs based on best practices and} previous experiences of states with existing markets. Biomass $\mathrm{CHP}$ qualifies for a large percentage of state incentives for renewable energy, but these do not seem to be well known or publicized. In some states, biomass-specific policies and programs may offer best practices if they can be measurably shown to increase the market. For example, Alabama, Arizona, and Maryland have wood stove purchase deductions or exemptions. Michigan uses U.S. Department of Energy State Energy Program dollars to fund a dedicated biomass grant program for education and infrastructure development for biomass CHP and biofuels. Since 1998, 10 of the 36 grant projects have been related to smaller scale biomass CHP projects or education (Michigan Department of Labor and Growth 2007). If 
other states understand these projects and incentives, they could learn how to develop and finance their own programs.

\section{Create "Best Choice" feedstock and technology development guidance for} project developers. Once the markets are identified, it will be helpful to develop interactive tools, fact sheets, or reports for the public and developers about the combination of appropriate fuel choices, available technologies, and feasibility studies.

NREL is working with the EPA to identify biomass utilization opportunities and provide state and local decision makers with tools to encourage biomass markets. Forthcoming resources include the EPA CHP Partnership's Biomass CHP Catalog of Technologies, a Biomass Toolkit for state and local government officials, as well as additional biomass CHP resources. This white-paper report, along with these other resources, offers a starting point for state and local policymakers interested in exploring or increasing their leadership to advance development of biomass CHP and other bioenergy markets. 


\section{References}

Bluestein, J. 2000. The Environmental Benefits of Distributed Generation. Energy and Environmental Analysis, Inc: Washington, DC.

Brown, E., Cory, K., and D. Arent. (2007). Understanding and Informing the Policy Environment: State Level Renewable Fuel Standards. TP-640-41075. NREL: Golden, CO.

Brown, E. and N. Elliott. 2005. On Farm Energy Use Characterizations. American Council for an Energy-Efficient Economy: Washington, DC.

Conference: Biomass for Energy and Industry: Proceedings of the Conference held 5-9

June 2000, Sevilla, Spain. London, UK: James \& James Ltd. Vol. I: pp. 65-68; NREL Report No. 31172.

Corbitt, R.A. (1990). Standard Handbook of Environmental Engineering. New York, NY: McGraw-Hill Inc.

[EPA] US Environmental Protection Agency. (2007). Air Emissions. www.epa.gov/solar/emissions.htm. Accessed August 2007.

[EPRI] Electric Power Research Institute. (1997). Renewable Energy Technology Characterizations. National Renewable Energy Laboratory and EPRI: Golden, CO.

Gagnon, L.; Belanger, C.; Uchiyama, Y. (2002). "Life-Cycle Assessment of Electricity Generation Options: The Status of Research in Year 2001.” Energy Policy 30(14):1267-1278. www.sciencedirect.com/science/article/B6V2W-46H216F1/2/98b06defa189e6fbe5065026ff7776a1.

Haq, Z. (2002). Biomass for Electricity Generation. Department of Energy, Energy Information Administration: Washington DC. http://www.eia.doe.gov/oiaf/analysispaper/biomass/index.html. Accessed August 2007.

Mann, M. K.; Spath, P. L. (2001). Comparison of the Environmental Consequences of Power from Biomass, Coal, and Natural Gas. Kyritsis, S., et al., eds. 1st World.

McKeever, D.B. (1998). "Wood Residual Quantities in the United States." BioCycle: Journal of Composting and Recycling, 39(1):65-68.

McNeil, D. (2001). Biomass Energy Opportunities in Nevada. Presentation to AB 661 Task Force for Renewable Energy and Energy Conservation. energy.state.nv.us/workgroups/biomass/recommendations.pdf. Accessed August 2007. 
Michigan Department of Labor and Economic Growth. (2007). Project Funding. www.michigan.gov/cis/0,1607,7-154-25676_25753_25761---,00.html

Milbrandt, A. (2005). Geographic Perspective on the Current Biomass Resource Availability in the United States. TP-560-39181. NREL: Golden, CO.

Morris, G. (1999). The Value of the Benefits of U.S. Biomass Power. NREL/SR-57027541. Work performed by the Green Power Institute of Berkeley, CA. Golden, CO: National Renewable Energy Laboratory. Available at www.eren.doe.gov/biopower/bplib/library/index.htm.

Murphy, D.P.L.; Helal, H.M. (1996). "Farming for Energy - Agronomic Principles and Environmental Impacts.” Energy from Crops. United Kingdom: Sumundo Limited.

Natural Scotland Scottish Executive. (2006). Review of Greenhouse Gas Life Cycle Emissions of Biomass Production and Consumption in Scotland. Environmental Research Report: SEERAD PROJECT FF/05/08. www.scotland.gov.uk/Resource/Doc/149415/0039781.pdf (1.2 MB).

NREL. (2005). Assessing the Potential for Renewable Energy on National Forest System Lands. NREL: Golden, CO.

NREL GIS. (2007). Maps and Supplemental information provided by NREL GIS Staff. National Renewable Energy Laboratory: Golden, CO. http://www.nrel.gov/gis. Accessed August 2007.

ORNL. (1999). Carbon Sequestration Research and Development. Oak Ridge National Laboratory: Oak Ridge, TN. www.osti.gov/energycitations/servlets/purl/8107229s7bTP/native/810722.PDF\%3E. Accessed August 2007.

Thompson, J. (1998). Directory \& Atlas of Solid Waste Disposal Facilities (1997-1998). Alexandria, VA: Chartwell Information Publishers.

Tolbert, V.; Joslin, J.D.; Thornton, F.C.; Bock, B.R.; Pettry D.E.; Bandaranayake W.; Tyler, D.; Houston, A.; Schoenhokz, S. (2000). "Increasing Below-Ground Carbon Sequestration with Conversion of Agricultural Lands to Production of Bio-Energy Crops.” New Zealand Journal of Forestry Science 30:138-149. 


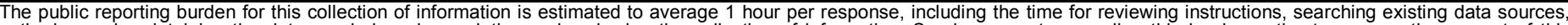

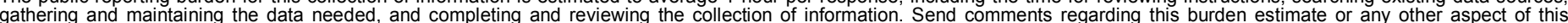

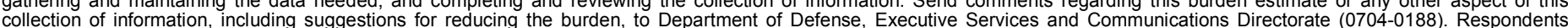

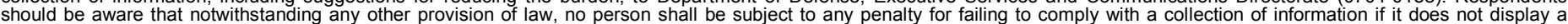

should be aware that notwithstanding

PLEASE DO NOT RETURN YOUR FORM TO THE ABOVE ORGANIZATION.

\begin{tabular}{l|l|l|l} 
1. REPORT DATE $(D D-M M-Y Y Y Y)$ & 2. REPORT TYPE & 3. DATES COVERED (FrOm - TO)
\end{tabular}

January 2008

White paper

4. TITLE AND SUBTITLE

Initial Market Assessment for Small-Scale Biomass-Based CHP

5a. CONTRACT NUMBER

DE-AC36-99-G010337

5b. GRANT NUMBER

5c. PROGRAM ELEMENT NUMBER

6. AUTHOR(S)

E. Brown and M. Mann

5d. PROJECT NUMBER

NREL/TP-640-42046

5e. TASK NUMBER

WF6N.1050

5f. WORK UNIT NUMBER
7. PERFORMING ORGANIZATION NAME(S) AND ADDRESS(ES)

National Renewable Energy Laboratory

1617 Cole Blvd.

Golden, CO 80401-3393
8. PERFORMING ORGANIZATION REPORT NUMBER

NREL/TP-640-42046

9. SPONSORING/MONITORING AGENCY NAME(S) AND ADDRESS(ES)

10. SPONSOR/MONITOR'S ACRONYM(S) NREL

11. SPONSORING/MONITORING AGENCY REPORT NUMBER

12. DISTRIBUTION AVAILABILITY STATEMENT

National Technical Information Service

U.S. Department of Commerce

5285 Port Royal Road

Springfield, VA 22161

13. SUPPLEMENTARY NOTES

14. ABSTRACT (Maximum 200 Words)

The purpose of this report is to reexamine the energy generation market opportunities for biomass CHP applications smaller than $20 \mathrm{MW}$. This paper provides an overview of the benefits of and challenges for biomass CHP in terms of policy, including a discussion of the drivers behind, and constraints on, the biomass CHP market. The report provides a summary discussion of the available biomass supply types and technologies that could be used to feed the market. Two primary markets are outlined_rural/agricultural and urban-for small-scale biomass CHP, and illustrate the primary intersections of supply and demand for those markets. The paper concludes by summarizing the potential markets and suggests next steps for identifying and utilizing small-scale biomass.

15. SUBJECT TERMS

Biomass CHP; Agricultural Markets; Municipal Markets; Biofuels; Policy makers; NREL; Elizabeth Brown; Margaret Mann

\begin{tabular}{|c|c|c|}
\hline $\begin{array}{l}\text { a. REPORT } \\
\text { Unclassified }\end{array}$ & $\begin{array}{l}\text { b. ABSTRACT } \\
\text { Unclassified }\end{array}$ & $\begin{array}{l}\text { c. THIS PAGE } \\
\text { Unclassified }\end{array}$ \\
\hline
\end{tabular}

\begin{tabular}{l|l} 
17. LIMITATION & 18. \\
OFUMBER \\
OF PAGES \\
UL
\end{tabular}

19a. NAME OF RESPONSIBLE PERSON

19b. TELEPHONE NUMBER (Include area code) 